\title{
Utilization of Application Program in Supporting Assessment of English Performance
}

\author{
Adityo $^{1}$ dan Agista Nidya Wardani ${ }^{2}$ \\ Universitas Muhammadiyah Malang, Jawa Timur, Indonesia \\ email: 1adityo@umm.ac.id
}

\begin{tabular}{|c|c|c|}
\hline \multicolumn{3}{|c|}{$\begin{array}{l}\text { ht in early years of school and become one of the main course in } \\
\text { he need of global society while not every school is able to offer } \\
\text { lack of qualified teachers. The evaluation needed in the learning } \\
\text { ty in which due to the lack of qualified teachers, is only capable of } \\
\text { aluation. Based on the phenomena, this research is conducted to } \\
\text { evaluating English course by using language tools software that } \\
\text { English teacher in accurate and valid evaluation and projected to } \\
\text { process in English course and able to support distance learning. } \\
\text { s quantitative analysis in a series of four data collections and } \\
\text { ir participants over the time of } 3 \text { months. This research is further } \\
\text { he analysis from language expert as a secondary instrument to } \\
\text { he analysis from the main instrument, P_LEX language tools. The } \\
\text { erformance as the result of the language analysis is in parallel to } \\
\text { se expert. }\end{array}$} \\
\hline \multicolumn{3}{|l|}{ Keywords: Language tool } \\
\hline & & \\
\hline & \\
\hline \multicolumn{3}{|l|}{$\begin{array}{r}\text { Adityo, \& Wardani, A. N } \\
\text { Assessment of En }\end{array}$} \\
\hline
\end{tabular}

\section{INTRODUCTION}

Understanding the teaching-learning process is a complex matter in which within the process there is so many factors involved and affected the process. Internal, external, and environmental factors are interconnected in a complex ways and bringing their important role of determining the successfulness of learning process (Larsen-Freeman, 2006) ${ }^{139}$. Internal factors such as motivation are closely related with external factors such as learning facilities, qualified teachers, and adequate interaction between teachers and students. Moreover, another factor plays its role in this complex system is the environment of learning in which the factor is closely related with the physical and psychological of the learners and teachers.

${ }^{139}$ Larsen-Freeman, D. (2006). The Emergence of Complexity, Fluency, and Accuracy in the Oral and Written Production of Five Chinese Learners of English. Applied Linguistics, 27 (4), 590-619

\section{Copyright (C) 2019 Schemata Journal}

Available online at http://journal.uinmataram.ac.id/index.php/schemata 
Adityo and Agista N. W., Utilization of Application Program in Supporting Assessment...

Affected by environment, the internal and external could be supported or weakened by the environment factor in which some elements of learning are not available.

Foreign language learning, similar to other learning courses, has more benefit in direct learning conduct with direct interaction and evaluation between the teacher and the improvement of the students (Tomlinson, 2012) ${ }^{140}$. This direct learning is common teaching method in the whole world including Indonesia. In practice, however, the vast archipelagic geographical condition in Indonesia often become a trouble for direct teaching and learning process and leave the remote area with the difficulties in comparison with the central with modern facility. The distant learning gives solution to the geographical and inequality problems such as that.

Distant learning is projected an adequate solution to solve the geographical problem in Indonesia. However, in the real life situation, distant learning has problem in the quality of the learning. The method used in the distant learning includes the online learning, designing module in independent learning, and sending teachers to the remote area. Although most of the methods could be the best way in distance learning, some of the elements of learning cannot be replaced. The most important element missing from those methods is the direct interaction with the language teacher in which within the interaction there is evaluation needed for direct feedback and wash up of the teaching and learning process (Llinares \& Dalton-Puffer, 2014 ${ }^{141}$. The loss of the evaluation can have a bad effect on the evaluation in distance learning because in the use of online media and using learning module, there is no adequate interaction involved, while sending the teachers to remote areas, in most of the case, has no adequate supply of teachers or available only with different field of knowledge.

Language tools are programs used in language analysis as a supporting device. With many variations of language tools, some of the language tools can be directed in language evaluation in terms of analysing vocabulary, grammar, or sentence complexity (Ellis, 2008) ${ }^{142}$. The use of language tools in learning process can be a supporting element to the teachers in conducting evaluation on the teaching-learning process, including the remote areas and environment without language teachers (Mitchell, 2013) ${ }^{143}$. In distant learning, the language

\footnotetext{
140 Tomlinson, B. (2013). Developing Materials for Language Teaching (2nd ed.). London: Bloomsbury.

${ }^{141}$ Llinares, A., \& Dalton-Puffer, C. (2014). The role of different tasks in CLIL students' use of evaluative language. System, 54, 69-79. https://doi.org/10.1016/j.system.2015.05.001

142 Ellis, N. C. (2008). The Dynamics of Second Language Emergence: Cycles of Language Use, Language Change, and Language Acquisition. The Modern Language Journal, 232-249

143 Mitchell, R., Myles, F., \& Marsden, E. (2013). Second Language Learning Theories. Oxon: Routledge.
}

\section{Copyright () 2019 Schemata Journal}


Adityo and Agista N. W., Utilization of Application Program in Supporting Assessment...

tools are projected as a supporting element in the evaluation stage in which the tools are able to represent the language teachers in evaluating the students, and the tools can be used even by educators of non-foreign language.

The problem of this research involves the question to what extent does the use of language tools supporting the evaluation process of English performance on the institution without language teachers. This research is purposed to test the validity of whether language tools is valid to be used in evaluation process of English vocabulary by comparing the evaluation from the tools with the evaluation from language expert.

Within the process of learning second or foreign language, there is an unpredictable complex process connected to the learning itself (De Bot, Lowie, \& Verspoor, 2007) ${ }^{144}$. The use of simple method such as pre-test and post-test can be defined as an accurate method, but this method needs direct interaction with language expert to interpret the connection between the variables and predict the learning process. Larsen-Freeman in her journal (Larsen-Freeman, 2006) ${ }^{145}$ explains the use of analytical tools in analysing the complexity of utterance from a learner as an accurate method. The term 'accurate' applied on the premises of no human error as language tools analyse the data through systematic and programmed way as there will not allow any mistakes or errors based on the factors such as tiredness or lack of knowledge from human.

\section{LITERATURE REVIEW}

Some previous researches has been implemented the use of language tools as their primary instrument in their researches. Larsen-Freeman $(2006)^{146}$ is suggesting the use of sophisticated way to analyse language by using some kind of analytical tools to analyse the complexity of vocabulary and propose it as an accurate and valid with error on the researcher rather than the tools. In the previous research conducted by the researcher (Adityo, 2014) ${ }^{147}$, the use of language tools become the primary instrument fulfilling the validity of the analysis in which the use of the language tools have the accuracy of analytical tools. The use of the

144 De Bot, K., Lowie, W., \& Verspoor, M. (2007). A Dynamics Systems Theory: approach to second language acquisition. Billingualism: Language and Cognition, 10(1), 7-21.

145 Larsen-Freeman, D. (2006). The Emergence of Complexity, Fluency, and Accuracy in the Oral and Written Production of Five Chinese Learners of English. Applied Linguistics , 27 (4), 590-619

${ }^{146}$ Larsen-Freeman, D. (2006). The Emergence of Complexity, Fluency, and Accuracy in the Oral and Written Production of Five Chinese Learners of English. Applied Linguistics, 27 (4), 590-619

147 Adityo. (2014). Dynamics Systems Theory and Second Language Acquisition in Relation to Indonesian Multilingual Learners of English in Natives Environment. London: Kingston University: Unpublished Dissertation 
Adityo and Agista N. W., Utilization of Application Program in Supporting Assessment...

language tools refers to the website Lognostics by Paul Meara (Meara, Lognostics, 2014) providing language tools with features specific to the language area and element of language being analysed in accurate way.

\section{RESEARCH METHOD}

The design of the research is quantitative method focused on the use of language tools as milestone in the English learning process of English class. This research is purposed to test the validity of using language tools in analysing English performance by comparing the result of the analysis from the tool with the analysis from language teacher as the expert in teaching and learning process. This research is based on the result of English for Specific Purposes course by using structured and independent evaluation process. Evaluation is conducted in two ways, the analysis from the language teacher and analysis by using language tool as requested by the researcher. The result of both analyses is compared to find out the validity of the analysis on the same competence with language expert. In this research, the language tool is considered valid if the result of the analysis is having similarity in dynamic system with the language expert, illustrated by using chart. The research is conducted on August to October 2019 by implementing four times data collection with the help of an assistant as enumerator to four participants. The participants are selected based on the advice of the language instructor as the holder of the authority in class. The data is taken by recording the utterances of each student and then transcribed into written form, in which the transcript becomes the basic of the analysis of the language tool. The analysis of this research is conducted based on language analysis from language expert by using range of 0 100 with 100 as the highest score, and language analysis from language tool P_LEX by using Lambda values with range $0-4.5$ with 4.5 as the highest score. In this research, Lambda is the value of the use of rare vocabulary used by the participants.

The topic of the transcribed utterances, as suggested in Larsen-Freeman (LarsenFreeman, 2006) ${ }^{148}$ is using the same topic over and over again to avoid any language bias on the preferred and less preferred topic (Gass, Mackey, Alvarez-Torres, \& Fernandez-Garcia, $1999)^{149}$. The selected topic in this research is inspiring people or idol as presumed that everyone has inspiring people or idol and can be easily talk about them.

148 Larsen-Freeman, D. (2006). The Emergence of Complexity, Fluency, and Accuracy in the Oral and Written Production of Five Chinese Learners of English. Applied Linguistics, 27 (4), 590-619

${ }^{149}$ Gass, S., Mackey, A., Alvarez-Torres, M. J., \& Fernandez-Garcia, M. (1999). The Effects of Task Repetition on Linguistic Output. Language Learning, 549-581

\section{Copyright $(9) 2019$ Schemata Journal}

Available online at http://journal.uinmataram.ac.id/index.php/schemata 
Adityo and Agista N. W., Utilization of Application Program in Supporting Assessment...

\section{a. Research Participants}

The subjects of this research are four selected students on a class of English for Specific Purposes (ESP) from non-language class on university level with parameters: students from the same class under the same language teacher and active on following the class schedule with the same quality and quantity during the period of the research. The subjects consist of two male and two female students to hinder the gender bias related to the language research and with the same age to hinder the age bias. The limitation of the biases is important related to the language complexity such as the wider the parameter of the participants, the wider the language variety and resulted in the validity of the data collected. In concerning with the research ethics related to the secrecy of the identity of the participants, the use of initials is applied to the participants by using the letter $A, N, K$, and $\mathrm{F}$ in representing the identity, and using the terms language expert in representing the language teacher.

\section{b. Research Instrument}

The research instrument used in this research is language tool P_LEX manufactured and designed by Paul Meara (Meara, 2014) ${ }^{150}$ and the second version by Paul Meara and Imma Miralpeix available in 'lognostics' website, designed to analyse the vocabulary rarity of the utterance (Meara \& Miralpeix, Lognostics, 2014) ${ }^{151}$ and assistance from ESP instructor in the form of scoring rubric. The language tool in the website is free and non-commercial to be used in language research. P_LEX analyses the use of rare vocabulary and present the values as Lambda. Lambda has the range of 0 to 4.5 by conducting analysis per segment in utterances of the participants. Those segments are analysed automatically by the P_LEX by categorising the words into difficult words and easy words. For every difficult word, the result will be compared with the average use of words in one sentence to find the Lambda value as the basic of comparison of the language performance by the participants

150 Meara, P. (2014, July 25). Lognostics. Retrieved from Lognostics: http://www.lognostics.co.uk

151 Meara, P., \& Miralpeix, I. (2014, January 1). Lognostics. Retrieved from Lognostics: http://www.lognostics.co.uk 
Adityo and Agista N. W., Utilization of Application Program in Supporting Assessment...

\section{FINDING AND DISCUSSION}

\section{A. P_LEX Scores}

Based on the purpose of the research, the use of P_LEX in analysing the language performance can be described in the form of table and narration as follow:

Table 1. The P_LEX Scores over 4 Times Data Analysis

\begin{tabular}{lllll}
\hline & A & N & K & F \\
\hline week 1 & 0,62 & 0,31 & 1,04 & 0,38 \\
week 2 & 0,38 & 0,15 & 0,56 & 0,37 \\
week 3 & 0,86 & 0,41 & 0,59 & 0,72 \\
week 4 & 0,8 & 0,27 & 0,89 & 0,29 \\
\hline
\end{tabular}

Based on the table, it can be narrated that after all of the participants being analysed, the value of P_LEX is dynamically changed over the time period. The changing of the Lambda values are normal as the language itself change over the time through a complex system. These change of the Lambda value over the time period become the data of the comparison with the score taken from the language expert. By using the Lambda value of the entire participant, it can be visualised by using a line chart to see the dynamics of the language performance based on the P_LEX.

Figure 1. The Graphic Visualisation on The Lambda Values of The Participant

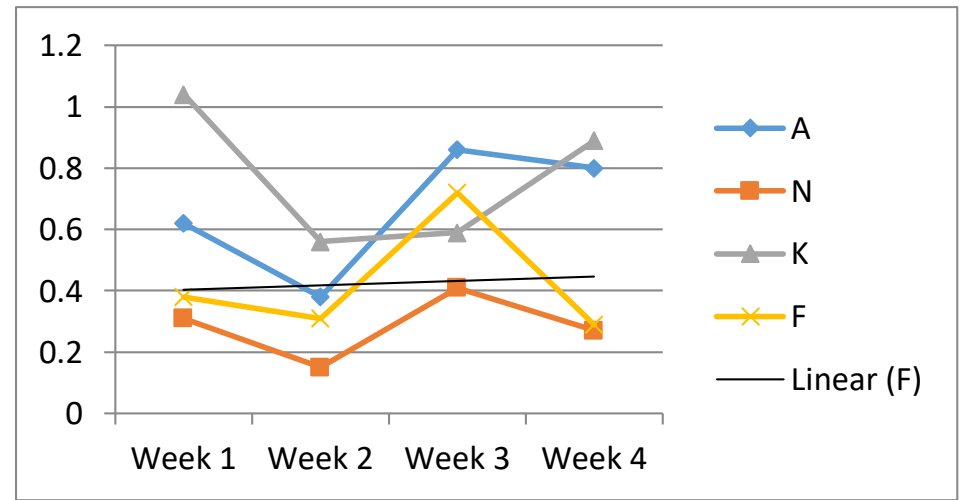

The figure shows the dynamics of the Lambda values or the language performance of the participants over the four times analysis (note the dynamics movement of the Lambda value of participant $\mathrm{A}$ is following the scores from the above analysis). 
Adityo and Agista N. W., Utilization of Application Program in Supporting Assessment...

\section{B. Language Experts Score}

In the analysis from the language experts, the scores are taken from evaluation process including the accuracy of the vocabulary and the length of the utterance of the participant. The data used in the analysis of the language expert is the same data with the data used in the P_LEX analysis. The result of the language expert analysis can be described in the below table:

Table 2. The Language Expert Scores over 4 Times Data Analysis

\begin{tabular}{lllll}
\hline & A & N & K & F \\
\hline week 1 & 80 & 79 & 78 & 78 \\
week 2 & 75 & 65 & 70 & 78 \\
week 3 & 80 & 70 & 70 & 79 \\
week 4 & 81 & 79 & 80 & 65 \\
\hline
\end{tabular}

Based on the scores from the language experts, it can be visualised by using a line chart to see the dynamics of the language performance based on the language expert.

Figure 2. The Graphic Visualisation on The Language Expert's Score of The Participants

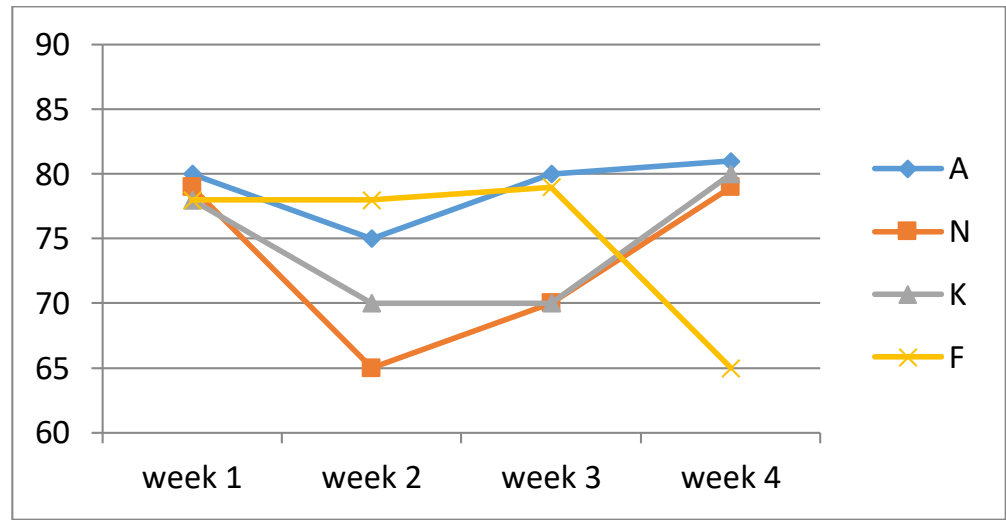

The figure 2 shows similarities to the figure 1 with only differences in the last score of participant $\mathrm{N}$ and the second score of participant $\mathrm{F}$. The overall movement of the participants' score are closely similar between the two figures.

On both of the figures above, the dynamics movement of the scores can be seen in similar shape. Both figures are similar in which both of the scoring system of the individuals have similar movement. In average of both figures, participant $\mathrm{A}$ and $\mathrm{K}$ are always in the higher position than the others, while the participant $\mathrm{N}$ is below the average of the other participants. To give a example, the participant A has similar dynamics average where on the second data analysis, the participant A had declining score in comparison with the first data 
Adityo and Agista N. W., Utilization of Application Program in Supporting Assessment...

analysis, then raised on the third data analysis and declined again on the fourth data. Based on this case, it can be said that the language tool and the language expert have similar scoring value on the same utterances and the same participants.

Based on the purpose of the research, it can be said that the analysis in quantitative is showing evidences on the validity of using language tool in the evaluation process of English language performance. In summary, language tool such as P_LEX is valid to be used as supporting device in helping the teacher in analysing the student's utterance.

\section{CONCLUSION}

It can be concluded from the research that both language tool and language expert scored the language ability of the participant majorly in the similar manner. While both manner can be used to score language ability, language tool can be operated without the assistance of an expert or language proficiency. The tool can be used to assist language learning in remote area in which English is taught as complimentary subject by using mobile learning or English module but with insufficient support of language experts.

\section{SUGGESTION}

It is suggested for the authority holder of the language policy to use language tool in the process of evaluating language learning, and it is also suggested to the teachers and educators to utilize technology in the process of teaching and learning.

\section{ACKNOWLEDGEMENT}

The acknowledgement is presented to the Direktorat Penelitian dan Pengabdian Masyarakat University of Muhammadiyah Malang for the financial support during the research.

\section{REFERENCES}

Adityo. (2014). Dynamics Systems Theory and Second Language Acquisition in Relation to Indonesian Multilingual Learners of English in Natives Environment. London: Kingston University: Unpublished Dissertation.

De Bot, K., Lowie, W., \& Verspoor, M. (2007). A Dynamics Systems Theory: approach to second language acquisition. Billingualism: Language and Cognition, 10(1), 7-21.

Ellis, N. C. (2008). The Dynamics of Second Language Emergence: Cycles of Language Use, Language Change, and Language Acquisition. The Modern Language Journal, 232-249.

Gass, S., Mackey, A., Alvarez-Torres, M. J., \& Fernandez-Garcia, M. (1999). The Effects of Task Repetition on Linguistic Output. Language Learning, 549-581.

\section{Copyright $\odot 2019$ Schemata Journal}

Available online at http://journal.uinmataram.ac.id/index.php/schemata 
Adityo and Agista N. W., Utilization of Application Program in Supporting Assessment...

Larsen-Freeman, D. (2006). The Emergence of Complexity, Fluency, and Accuracy in the Oral and Written Production of Five Chinese Learners of English. Applied Linguistics, 27(4), 590-619.

Llinares, A., \& Dalton-Puffer, C. (2014). The role of different tasks in CLIL students' use of evaluative $\quad$ language. System, $\quad 54, \quad 69-79$. https://doi.org/10.1016/j.system.2015.05.001

Meara, P. (2014). Lognostics. Retrieved from Lognostics: http://www.lognostics.co.uk

Meara, P., \& Miralpeix, I. (2014). Lognostics. Retrieved from Lognostics: http://www.lognostics.co.uk Mitchell, R., Myles, F., \& Marsden, E. (2013). Second Language Learning Theories. Oxon: Routledge. Tomlinson, B. (2013). Developing Materials for Language Teaching (2nd ed.). London: Bloomsbury. 
Schemata: Jurnal Pasca Sarjana UIN Mataram is a double blind review journal which has been published Universitas Islam Negeri (UIN) Mataram since 2012. The scope of the Schemata includes Interdisciplinary Islamic Studies. Schemata receive manuscripts as the product of research results, both field research, and library research. Since 2017, Schemata has been accessible through http://journal.uinmataram.ac.id/index.php/schemata 